\author{
Aleksandra Pieloch-Babiarz \\ Uniwersytet Łódzki, Wydział Ekonomiczno-Socjologiczny, \\ Katedra Analizy i Strategii Przedsiębiorstwa, apieloch@uni.lodz.pl
}

\title{
Koncentracja własności i kontroli a wypłaty dywidendy pieniężnej w spółkach przemysłowych notowanych na GPW w Warszawie
}

\begin{abstract}
Streszczenie: Celem artykułu jest przedstawienie wyników badań empirycznych nad związkiem stopnia koncentracji własności i kontroli z regularnością i wysokością wypłacanej dywidendy pieniężnej. Dla jego realizacji sformułowane zostały dwie hipotezy badawcze - hipoteza H1 stanowiąca, iż spółki o dużym stopniu koncentracji własności i kontroli wypłacają dywidendę regularniej niż pozostałe jednostki, oraz hipoteza H2 stwierdzająca, że w spółkach, w których własność i kontrola skupione są w rękach inwestorów strategicznych, obserwuje się wyższe wypłaty dywidendy niż w przedsiębiorstwach z rozproszonym akcjonariatem. Badanie przeprowadzone zostało na spółkach przemysłowych notowanych na Giełdzie Papierów Wartościowych w Warszawie w latach 2010-2015. Rezultaty badań empirycznych potwierdziły obie hipotezy.
\end{abstract}

Słowa kluczowe: koncentracja własności, polityka dywidendy, przedsiębiorstwa przemysłowe JEL: G10, G31, G35 


\section{Wprowadzenie}

Jedną z najważniejszych strategicznych decyzji finansowych podejmowanych przez właścicieli spółki akcyjnej jest podział osiągniętego zysku netto na część pozostawioną w przedsiębiorstwie i część wypłaconą akcjonariuszom w formie dywidendy. Możliwość realizacji polityki wypłat uzależniona jest od wielu czynników, w tym m.in. od struktury akcjonariatu spółki oraz związanego z nią stopnia koncentracji własności i kontroli.

Zasadniczym celem artykułu jest przedstawienie wyników badań empirycznych nad związkiem stopnia koncentracji własności i kontroli z regularnością i wysokością wypłacanej dywidendy pieniężnej. Postawiony cel opracowania należy do zasadniczych problemów nadzoru korporacyjnego (corporate governance). Dla jego realizacji sformułowane zostały dwie następujące hipotezy badawcze:

1) hipoteza $\mathrm{H} 1$ stanowiąca, iż spółki o dużym stopniu koncentracji własności i kontroli wypłacają dywidendę regularniej niż pozostałe jednostki;

2) hipoteza $\mathrm{H} 2$ stwierdzająca, że w spółkach, w których własność i kontrola skupione są w rękach inwestorów strategicznych ${ }^{1}$, obserwuje się wyższe wypłaty dywidendy niż w przedsiębiorstwach $\mathrm{z}$ rozproszonym akcjonariatem.

Takie sformułowanie hipotez badawczych wynika bezpośrednio z samej istoty spółki kapitałowej, w której następuje rozdzielenie własności kapitału od możliwości zarządzania przedsiębiorstwem. Właściciele (inwestorzy) powierzają prowadzenie spółki menedżerom (agentom), oczekując m.in. satysfakcjonującego dochodu z inwestycji w drodze wzrostu wartości rynkowej spółki i wypłaty dywidendy. Cele akcjonariuszy nie zawsze realizowane są w takim stopniu, jaki zakładali. Ponadto mogą one odbiegać od celów, które zamierzała zrealizować kadra kierownicza. Rozbieżność celów prowadzić może do występowania konfliktów między właścicielami a zarządem spółki (Jensen, 1986: 323-329). Ograniczanie konfliktów, egzekwowanie praw właścicieli kapitału, jak również kontrola działań zarządu i wpływ na podejmowane przez menedżerów decyzje, są zadaniami nadzoru korporacyjnego. Różne systemy corporate governance odznaczają się odmienną strukturą akcjonariatu i możliwością kontroli zarządu spółek. Im większa koncentracja własności, tym silniejsza może być kontrola i nacisk na realizację celów akcjonariuszy, w tym m.in. na wypłatę regularnych i wysokich dywidend.

${ }^{1}$ Termin ,inwestor strategiczny” i ,akcjonariusz większościowy” traktowane są w tej pracy jako synonimy. 


\section{Wybrane czynniki determinujące wypłatę dywidendy pieniężnej}

Nabywając akcje spółki, inwestor giełdowy staje się jej właścicielem i podmiotem praw majątkowych, korporacyjnych i mniejszościowych wynikających z posiadania udziału w spółce. Jednym z podstawowych praw majątkowych wspólnika jest prawo do udziału w zysku netto przedsiębiorstwa, wykazanego w sprawozdaniu finansowym za ostatni rok obrotowy, które poddane zostało badaniu przez biegłego rewidenta (Kodeks spółek handlowych, art. 347 § 1). Prawo to ma charakter bezwzględny, co oznacza, że akcjonariusz nie może być go pozbawiony w drodze zapisów w statucie spółki lub uchwały walnego zgromadzenia wspólników (Binek i in., 2006: 21). Realizacja tego prawa może odbywać się z wykorzystaniem zróżnicowanych form wypłaty dywidendy ${ }^{2}$. Praktyka rynków kapitałowych ${ }^{3}$ pokazuje, że partycypacja akcjonariuszy w zysku netto spółki może wystąpić pod postacią (Duraj, 2002: 55-58; Sierpińska, 1999: 13-15; Pieloch, 2013: 433-448): wypłaty dywidendy pieniężnej (w formie dywidendy zwykłej, dodatkowej, specjalnej, likwidacyjnej i rezydualnej) i/lub dywidendy niepieniężnej (w postaci dywidendy rzeczowej lub akcyjnej $)^{4}$. Realizacja prawa akcjonariusza do udziału w zysku netto ma miejsce niezależnie od formy dywidendy ${ }^{5}$. Możliwość partycypowania w dodatnim wyniku finansowym netto przedsiębiorstwa uwarunkowana jest wieloma zróżnicowanymi determinantami wypłaty dywidendy. Wśród najważniejszych czynników warunkujących podjęcie decyzji o wypłacie dywidendy należy wymienić czynniki mikroekonomiczne, makroekonomiczne i behawioralne. Pierwsze z nich związane są m.in. z kondycją finansową przedsiębiorstwa, wiekiem spółki, możliwościami rozwojowymi, stabilnością prowadzonej polityki wypłaty dywidendy i wielkością przedsiębiorstwa. Do czynników makroekonomicznych determinujących wypłatę dywidendy zaliczyć można np. sytuację gospodarczą

${ }^{2}$ Alternatywą dla wypłaty dywidendy jest np. nabycie akcji własnych. Wskazać jednakże należy, iż cele, przyczyny i rezultaty jego przeprowadzenia są odmienne w relacji do celów, motywów i efektów wypłaty dywidendy (Pieloch, 2012).

${ }^{3}$ Kodeks spółek handlowych (k.s.h.) nie precyzuje, czy dywidenda może być wypłacana jedynie w formie pieniężnej, czy też może przyjąć inną postać. Dopuszczalność dywidendy niepieniężnej przyjęta została przez doktrynę prawną i potwierdzona przez praktykę gospodarczą.

${ }^{4} \mathrm{Na}$ rynku amerykańskim dywidenda niepieniężna wypłacana w formie akcji (ang. stock dividend) jest popularnym sposobem realizacji praw majątkowych akcjonariuszy, m.in. ze względu na jej preferencyjne opodatkowanie. Z kolei na GPW w Warszawie ta postać dywidendy występuje bardzo rzadko. Miała ona miejsce m.in. w: Famur SA (dywidenda wypłacona w formie aktywów finansowych), Kredyt Inkaso SA (dywidenda w formie akcji) oraz PGNiG SA (dywidenda rzeczowa) (Pieloch, 2013: 433-448).

${ }^{5}$ Wypłata dywidendy uwarunkowana jest wypracowaniem przez spółkę zysku netto za ostatni rok obrotowy lub posiadaniem środków stanowiących tzw. sumę dywidendową będącą kwotą przeznaczoną do podziału między akcjonariuszy (art. 348 k.s.h.). 
kraju, system prawny konstytuujący formy prowadzenia działalności gospodarczej i zróżnicowane wysokości stóp podatku dochodowego. Natomiast czynniki behawioralne obejmują m.in.: preferencje i działania inwestorów krótko- i długoterminowych, efekt zakotwiczenia i księgowanie mentalne, premię dywidendową i behawioralne podejście do koniunktury giełdowej (zob. tab. 1).

Wśród czynników mikroekonomicznych, mogących warunkować podjęcie decyzji o wypłacie dywidendy, należy wskazać także strukturę właścicielską przedsiębiorstwa, rozumianą jako wysokość udziałów kapitałowych posiadanych przez określone grupy akcjonariuszy (Wypych, 2015: 785). Struktura akcjonariatu może być rozpatrywana z punktu widzenia koncentracji własności (np. własność skoncentrowana $w$ rękach akcjonariusza strategicznego, inwestorów blokowych czy akcjonariatu rozproszonego), jak również typów akcjonariuszy (m.in. inwestorzy instytucjonalni, inwestorzy indywidualni, Skarb Państwa czy kadra menedżerska posiadająca udział w strukturze własności) (Hamrol, Ochocki, 2008: 288).

Tabela 1. Podstawowe czynniki warunkujące możliwość wypłaty dywidendy pieniężnej

\begin{tabular}{|c|c|}
\hline Determinanty & Wpływ czynnika na podjęcie decyzji o wypłacie dywidendy \\
\hline \multicolumn{2}{|r|}{ Czynniki mikroekonomiczne } \\
\hline $\begin{array}{l}\text { Kondycja finan- } \\
\text { sowa przedsię- } \\
\text { biorstwa }\end{array}$ & $\begin{array}{l}\text { Prawdopodobieństwo wypłaty dywidendy maleje: } \\
\text { - wraz ze wzrostem dźwigni finansowej (wzrost zadłużenia zwięk- } \\
\text { sza koszty pozyskania źródeł finansowania spółki, a w konse- } \\
\text { kwencji również ryzyko jej działalności; ponadto spółki z wyso- } \\
\text { kim poziomem zadłużenia mogą wykazywać mniejszą skłonność } \\
\text { do wypłaty dywidendy w przypadku, gdy wykorzystują zyski } \\
\text { netto do spłaty swoich zobowiązań) (Jensen, Solberg, Zorn, 1992: } \\
\text { 247-263); } \\
\text { - wraz z niższą rentownością przedsiębiorstwa (według teorii sy- } \\
\text { gnalizacji spółki, które osiągają wysokie zyski netto, będą wy- } \\
\text { płacać dywidendę w celu przekazania na rynek pozytywnego } \\
\text { sygnału o ich kondycji finansowej) (Kaźmierska-Jóźwiak, 2014: } \\
\text { 129-135); } \\
\text { - wraz ze zmniejszeniem lub utratą płynności finansowej oraz bra- } \\
\text { kiem wolnych przepływów pieniężnych (zgodnie z teorią agencji } \\
\text { przedsiębiorstwa wysoce płynne finansowo będą dążyć do wypła- } \\
\text { ty dywidendy w celu obniżenia kosztów agencji) (La Porta, Lo- } \\
\text { pez, Shleifer, Vishny, 2000: 34); } \\
\text { - wraz ze wzrostem niepewności co do przyszłej kondycji finanso- } \\
\text { wej spółki (Eije, Megginson, 2008: 347-374). }\end{array}$ \\
\hline
\end{tabular}




\begin{tabular}{|c|c|}
\hline Determinanty & Wpływ czynnika na podjęcie decyzji o wypłacie dywidendy \\
\hline $\begin{array}{l}\text { Wiek przedsię- } \\
\text { biorstwa i jego } \\
\text { możliwości in- } \\
\text { westycyjne }\end{array}$ & $\begin{array}{l}\text { Spółki będące na różnych etapach rozwoju i w różnych fazach cyklu } \\
\text { życia wykazują odmienne zapotrzebowanie na różne źródła finanso- } \\
\text { wania, mają inne możliwości inwestycyjne, charakteryzują się róż- } \\
\text { nym ryzykiem operacyjnym i finansowym. We wczesnych fazach } \\
\text { cyklu życia przedsiębiorstwa mają zwykle sposobność realizacji } \\
\text { efektywnych projektów inwestycyjnych finansowanych m.in. kapi- } \\
\text { tałem własnym. Wykorzystanie zysku netto na rozwój może skut- } \\
\text { kować brakiem lub niewielkimi wypłatami dywidendy (Sierpińska, } \\
\text { 1999). Z kolei przedsiębiorstwa dojrzałe są bardziej skłonne do wy- } \\
\text { płaty dywidendy ze względu na mniejsze możliwości inwestycyjne } \\
\text { i/lub większe szanse pozyskania na rozwój tańszych kapitałów ob- } \\
\text { cych (DeAngelo, DeAngelo, Stulc, 2006: 227-254). Ponadto wypła- } \\
\text { ta dywidendy rzadko ma miejsce w pierwszych latach po prywaty- } \\
\text { zacji przedsiębiorstw (Matuszewska-Pierzynka, 2015: 89). }\end{array}$ \\
\hline $\begin{array}{l}\text { Stabilność } \\
\text { przyjętej po- } \\
\text { lityki wypła- } \\
\text { ty dywidendy } \\
\text { (,lepkość” lub } \\
\text { „sztywność" dy- } \\
\text { widend) }\end{array}$ & $\begin{array}{l}\text { Menedżerowie przekonani o tym, że akcjonariusze preferują stabil- } \\
\text { ną stopę wypłat dywidendy, niechętnie podejmują decyzje o jakiej- } \\
\text { kolwiek zmianie w zakresie wypłaty dywidendy. Sprawia to, że po- } \\
\text { lityka dywidendy charakteryzuje się swoistą „lepkością” (Lintner, } \\
\text { 1956: 99), co oznacza, że zmiany w polityce dywidendy tylko czę- } \\
\text { ściowo uwzględniają zmiany poziomu wyniku finansowego netto. } \\
\text { Jest to tzw. polityka częściowych dopasowań, która ma prowadzić } \\
\text { do stabilnej polityki dywidendy i chronić wartość rynkową spółki } \\
\text { przed negatywną reakcją inwestorów. }\end{array}$ \\
\hline $\begin{array}{l}\text { Wielkość przed- } \\
\text { siębiorstwa }\end{array}$ & $\begin{array}{l}\text { Większe przedsiębiorstwa wypłacają dywidendę relatywnie częściej } \\
\text { niż pozostałe podmioty. Może to być związane m.in. z fazą cyklu } \\
\text { życia przedsiębiorstwa, jego możliwościami rozwoju lub dojrzało- } \\
\text { ścią sektora, w którym prowadzi działalność. Ponadto duże spółki } \\
\text { prowadzą często działalność bardziej zdywersyfikowaną niż małe } \\
\text { podmioty, a więc w mniejszym stopniu są one obarczone ryzykiem } \\
\text { bankructwa. Łatwiej im również pozyskać tańszy kapitał na rozwój } \\
\text { (Kaźmierska-Jóźwiak, 2014: 129-135). }\end{array}$ \\
\hline \multicolumn{2}{|r|}{ Czynniki makroekonomiczne } \\
\hline $\begin{array}{l}\text { Sytuacja gospo- } \\
\text { darcza/cykl ko- } \\
\text { niunkturalny }\end{array}$ & $\begin{array}{l}\text { Sytuacja gospodarcza może mieć istotny wpływ na kształtowa- } \\
\text { nie się polityki dywidendowej przedsiębiorstw. Wraz ze wzrostem } \\
\text { wskaźnika tempa wzrostu PKB zwiększa się liczba przedsiębiorstw } \\
\text { wypłacających dywidendę (Kowerski, 2010: 19-34). }\end{array}$ \\
\hline System prawny & $\begin{array}{l}\text { Możliwość wypłaty dywidendy zależy nie tylko od uregulowań } \\
\text { prawnych, które dopuszczają wypłatę dywidendy w podmiotach } \\
\text { prowadzonych w określonej formie organizacyjno-prawnej, ale rów- } \\
\text { nież warunkowana jest systemem prawnym danego kraju. W syste- } \\
\text { mie anglosaskim, charakteryzującym się większą ochroną akcjona- } \\
\text { riuszy niż w systemie kontynentalnym, przedsiębiorstwa są bardziej } \\
\text { skłonne do płacenia dywidend (Eije, Megginson, 2008: 347-374). }\end{array}$ \\
\hline
\end{tabular}




\begin{tabular}{|c|c|}
\hline Determinanty & Wpływ czynnika na podjęcie decyzji o wypłacie dywidendy \\
\hline $\begin{array}{l}\text { Zróżnicowane } \\
\text { wysokości stóp } \\
\text { podatku docho- } \\
\text { dowego }\end{array}$ & $\begin{array}{l}\text { W tych systemach podatkowych, w których stawka podatku od dy- } \\
\text { widend jest wyższa niż stawka podatku od zysków kapitałowych, } \\
\text { inwestorzy giełdowi powinni preferować dochody w postaci przyro- } \\
\text { stu wartości rynkowej spółki. Okazuje się jednak, że spółki wypła- } \\
\text { cają dywidendy niezależnie od wysokości opodatkowania } \\
\text { (tzw. zagadka dywidendy) (Black, 1976: 634-639). }\end{array}$ \\
\hline \multicolumn{2}{|r|}{ Czynniki behawioralne i preferencje inwestorów giełdowych } \\
\hline $\begin{array}{l}\text { Preferencje in- } \\
\text { westorów krót- } \\
\text { koterminowych }\end{array}$ & $\begin{array}{l}\text { Pewna grupa inwestorów krótkoterminowych, którzy stosują strate- } \\
\text { gię „,zbierania” dywidendy polegającą na kupnie akcji w celu ich po- } \\
\text { siadania w dniu ustalenia prawa do dywidendy, a następnie na szyb- } \\
\text { kiej ich odsprzedaży, dążyć będzie do wypłaty dywidendy (French } \\
\text { i in., 2005: 361). Celem spekulantów rynkowych będzie realizacja } \\
\text { korzyści finansowych głównie w formie zysków kapitałowych. }\end{array}$ \\
\hline $\begin{array}{l}\text { Preferencje in- } \\
\text { westorów dłu- } \\
\text { goterminowych } \\
\text { i efekt klienteli }\end{array}$ & $\begin{array}{l}\text { Ci inwestorzy długoterminowi, którzy traktują dywidendę jako } \\
\text { część swoich regularnych dochodów, szukają możliwości nabycia } \\
\text { akcji, które wypłacać będą regularne i wysokie dywidendy (Gajdka, } \\
\text { 2013: 130). Jeżeli oczekiwania akcjonariuszy co do wypłaty dywi- } \\
\text { dendy zostaną spełnione, mówimy o tzw. magnetyzmie dywidendy } \\
\text { (Duraj, 2002: 138). }\end{array}$ \\
\hline $\begin{array}{l}\text { Efekt zakotwi- } \\
\text { czenia i księgo- } \\
\text { wanie mentalne }\end{array}$ & $\begin{array}{l}\text { Inwestorzy giełdowi często „zakotwiczają” się w przekonaniu, } \\
\text { że przyszłe wartości stopy dywidendy }(D Y) \text { będą kształtowały się } \\
\text { na poziomie zbliżonym do jej wartości historycznych (Fisher, Stat- } \\
\text { man, 2000: 72-81). Poziom stopy dywidendy, który jest niezgodny } \\
\text { z oczekiwaniami rynku, może skutkować spadkiem rynkowej war- } \\
\text { tości przedsiębiorstwa. Aby uchronić się przed taką sytuacją, spółki } \\
\text { mogą odpowiednio kształtować wysokość dywidendy. Na wypłatę } \\
\text { dywidendy może mieć też wpływ księgowanie mentalne (Szyszka, } \\
\text { 2013: 38). Jedną z jego zasad jest zasada łączenia mniejszej straty } \\
\text { z większym zyskiem. Inwestorzy giełdowi posiadający akcje spół- } \\
\text { ek, których wartość rynkowa spadła, będą oczekiwać wypłaty dy- } \\
\text { widendy w wysokości, która zrekompensuje im przyszłą/potencjal- } \\
\text { ną stratę kapitałową. }\end{array}$ \\
\hline $\begin{array}{l}\text { Premia za dywi- } \\
\text { dendę }\end{array}$ & $\begin{array}{l}\text { Cateringowa teoria dywidendy zakłada, że w przypadku, gdy rynek } \\
\text { kapitałowy wyżej wycenia spółki dywidendowe niż te, które dy- } \\
\text { widendy nie wypłacają (czyli premia za dywidendę jest dodatnia), } \\
\text { menedżerowie będą dążyć do zaspokojenia potrzeb akcjonariuszy } \\
\text { w drodze wypłaty dywidendy (Baker, Wurgler, 2004: 1125). }\end{array}$ \\
\hline
\end{tabular}




\begin{tabular}{|l|l|}
\hline \multicolumn{1}{|c|}{ Determinanty } & \multicolumn{1}{|c|}{ Wpływ czynnika na podjęcie decyzji o wypłacie dywidendy } \\
\hline $\begin{array}{l}\text { Koniunktura } \\
\text { giełdowa }\end{array}$ & $\begin{array}{l}\text { W finansach behawioralnych panuje pogląd, że jeżeli w odczuciu } \\
\text { inwestorów giełdowych ogólne możliwości wzrostu gospodarcze- } \\
\text { go są duże, będą oni preferować spółki niewypłacające dywidendy, } \\
\text { gdyż uznają, że lepiej przeznaczyć wypracowany zysk na realiza- } \\
\text { cję projektów inwestycyjnych. W przeciwnym przypadku inwe- } \\
\text { storzy będą preferować spółki dywidendowe (Gajdka, 2013: 143), } \\
\text { co uwidocznione zostanie w relatywnie wyższej wycenie rynkowej } \\
\text { tych spółek w okresach dekoniunktury giełdowej (Fuller, Goldstein, } \\
\text { 2011: 457). Ponadto wypłata dywidendy w okresach bessy pozwala } \\
\text { zmniejszyć percepcję straty akcjonariusza. }\end{array}$ \\
\hline
\end{tabular}

Źródło: opracowanie własne

Strukturę akcjonariatu należy analizować także w kontekście możliwości sprawowania kontroli nad spółką. Kontrola decyzji podejmowanych przez kadrę kierowniczą może być przeprowadzana przez akcjonariusza dominującego. W takim przypadku mówimy o zamkniętym systemie nadzoru korporacyjnego (tzw. systemie wewnętrznym lub insiderskim). Kontrola ma wtedy charakter bezpośredni, co sprawia, że rozbieżność interesów właścicieli i menedżerów spółki jest stosunkowo niewielka. Z kolei w systemie otwartym (tzw. zewnętrznym lub outsiderskim) własność jest rozproszona, w związku z czym sprawowanie kontroli nad spółką jest utrudnione (Adamska, 2001: 68). Rozdrobniony akcjonariat nie jest w stanie skutecznie realizować swoich celów, co prowadzić może do większej niezależności zarządu spółek (Wypych, 2015: 785). Ponadto możliwość kontroli zarządu i realizacja celów akcjonariuszy uzależniona jest również od tego, jaki model systemu nadzoru korporacyjnego występuje w danym kraju. W systemach zorientowanych rynkowo (model anglosaski) ochrona właścicieli jest większa. Z tego też względu wypłaty dywidendy są zwykle wyższe niż w przypadku systemów zorientowanych sieciowo (Mitton, 2005: 409-426).

Prowadzone dotychczas badania nad determinantami wypłaty dywidendy nie dały jednoznacznej odpowiedzi na pytanie o kierunek zależności między stopniem koncentracji własności i kontroli a skłonnością przedsiębiorstw do wypłaty dywidendy. Jednokierunkową zależność między badanymi zmiennymi zaobserwowano m.in. na rynku brytyjskim (Short, Zhang, Keasay, 2002: 105-122), czeskim (Claessens, Djankov, 1999: 498-513), polskim (Wypych, 2015: 783-792), tureckim (Aydin, Cavdar, 2015: 66-76), malezyjskim (Ramli, 2010: 170-180) czy pakistańskim (Ullah, Fida, Khan, 2012: 298-307). Z kolei dwukierunkowe powiązanie zmiennych zaobserwowano m.in. na rynku niemieckim (Elson, Hofler, Lee, 2011: 89-102; Gugler, Yurtoglu, 2003: 731-758), brytyjskim (Renneboog, Trojanowski, 2005) oraz polskim (Kowalewski, Stetsyuk, Talavera, 2007: 60-86). 


\section{Metodyka badań empirycznych}

Badania empiryczne przeprowadzone zostały na grupie 146 spółek, które notowane były na Giełdzie Papierów Wartościowych w Warszawie w każdym z lat 2010-2015. Poddane analizie spółki należały do czternastu sektorów przemysłowych.

W pierwszym etapie analizy spółki z grupy badawczej podzielone zostały pod względem stopnia koncentracji własności i kontroli. Rozpatrując strukturę akcjonariatu w kontekście modeli sprawowania nadzoru korporacyjnego i typów dominujących właścicieli, przyjęto pewną umowną klasyfikację badanych spółek (zob. rys. 1). Klasyfikacja ta przeprowadzona została w oparciu o następujące założenia badawcze (Wypych, 2015: 786):

1) akcjonariuszem strategicznym jest inwestor indywidualny lub instytucjonalny, który posiada pakiet akcji zapewniający więcej niż 50\% głosów na walnym zgromadzeniu akcjonariuszy (WZA) lub pakiet kontrolny akcji przekraczający $33 \%$ głosów, jeżeli wraz z innym podmiotem powiązanym kapitałowo posiada więcej niż 50\% głosów na WZA; ponadto za akcjonariusza strategicznego przyjęto również Skarb Państwa, w przypadku którego kryterium posiadania powyżej 50\% głosów na walnym zgromadzeniu akcjonariuszy nie musi być spełnione;

2) wśród akcjonariuszy strategicznych wyróżnia się:

- krajowe i zagraniczne osoby fizyczne, rozumiane jako inwestorzy indywidualni posiadający pakiet akcji dający im ponad 50\% głosów na WZA,

- $\quad$ krajowe i zagraniczne osoby prawne, czyli inwestorów instytucjonalnych posiadających pakiet akcji dający ponad 50\% ogólnej liczby głosów,

- $\quad$ krajowe i zagraniczne firmy niepowiązane kapitałowo, rozumiane jako grupa kilku niepowiązanych kapitałowo spółek posiadających takie pakiety akcji, których łączne posiadanie przekracza 50\% głosów na walnym zgromadzeniu akcjonariuszy,

- $\quad$ krajowe i zagraniczne grupy osób fizycznych złożone z kilku niepowiązanych więzami rodzinnymi inwestorów indywidualnych, którzy posiadają łącznie pakiet kontrolny akcji;

3) akcjonariat rozproszony dominuje w tych spółkach, w których większość inwestorów posiada niewielkie pakiety akcji (tj. taką liczbę akcji, które dają mniej niż 5\% głosów na WZA), nie są to akcje zastrzeżone i nie należą do insiderów; ponadto żaden $\mathrm{z}$ akcjonariuszy nie jest inwestorem znaczącym, czyli nie posiada więcej niż $20 \%$ głosów na walnym zgromadzeniu akcjonariuszy. 


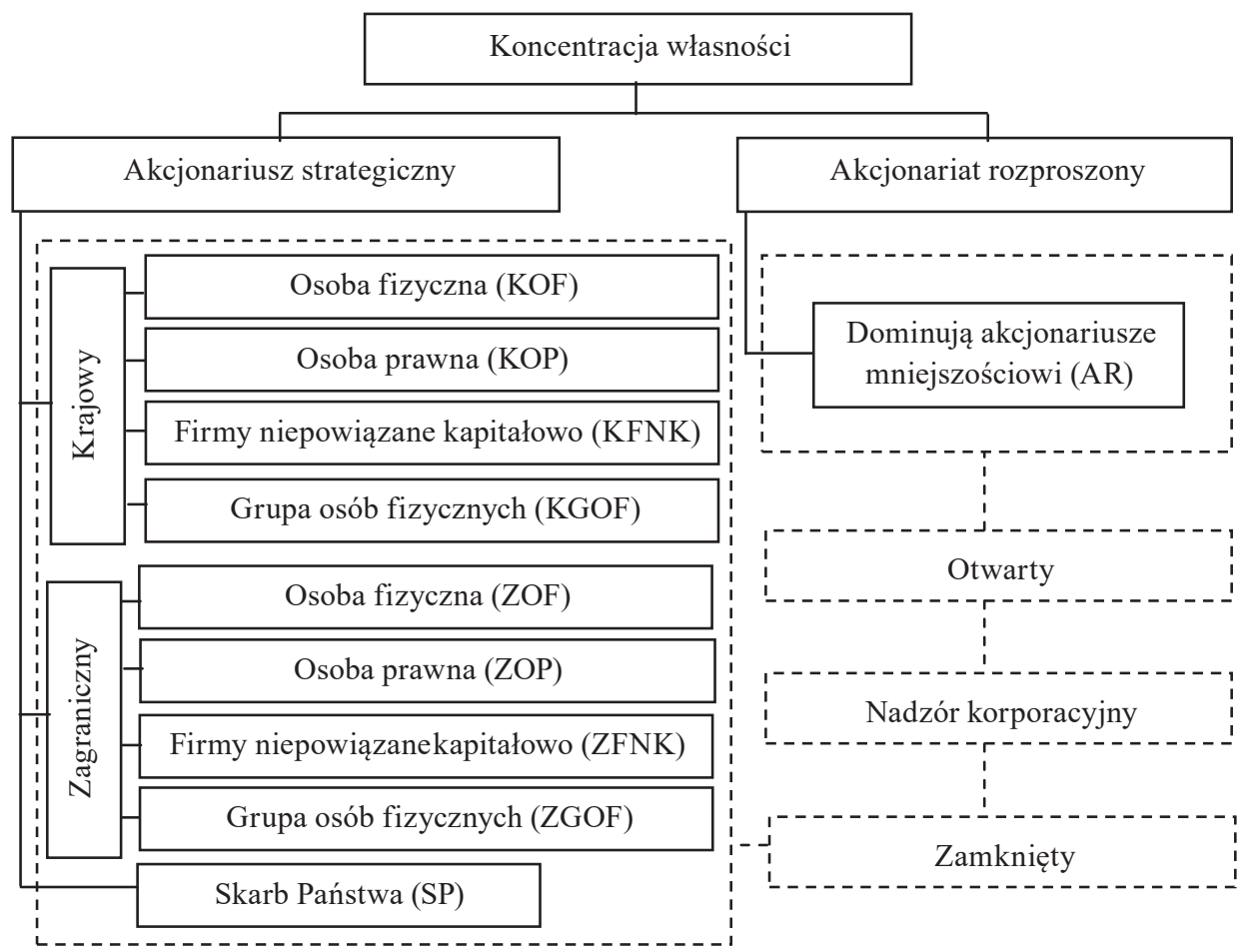

Rysunek 1. Klasyfikacja badanych podmiotów według kryterium modelu sprawowania nadzoru korporacyjnego nad spółką i typów dominujących akcjonariuszy

Źródło: opracowanie własne na podstawie: Wypych, 2015: 786

W celu empirycznej weryfikacji hipotezy badawczej H1 analizie poddano przedsiębiorstwa wypłacające dywidendę w sposób regularny i nieregularny ${ }^{6}$, a następnie zbadano ich udział w ogóle analizowanych spółek z uwzględnieniem stopnia koncentracji własności i kontroli. Występowanie korelacji między regularnością wypłaty dywidendy a strukturą akcjonariatu oceniono, wykorzystując współczynnik niezależności $\chi^{2}$, a siłę tej zależności obliczono, posługując się współczynnikiem kontyngencji C-Pearsona (Domański, 2001: 183-185).

W kolejnym etapie poddano empirycznej weryfikacji hipotezę H2. Analiza wysokości wypłacanej dywidendy względem struktury właścicielskiej przeprowadzona została z wykorzystaniem współczynnika dywidendy na akcję (DPS) oraz stopy wypłat dywidendy (DPR) (Jerzemowska, 2004: 325), dla których wy-

${ }^{6} \mathrm{Za}$ regularne wypłaty dywidendy rozumie się, zgodnie z przyjętą przez GPW w Warszawie metodologią budowy portfela spółek tworzących indeks WIGdiv, takie wypłaty z zysku netto na rzecz akcjonariuszy, które miały miejsce co najmniej trzy razy w ciągu 5 lat okresu badawczego. W pozostałych przypadkach wypłatę dywidendę uznano za nieregularną (Rocznik Giełdowy, 2013: 104). 
znaczono wartości średnie i mediany. Następnie zweryfikowano hipotezę o równości średnich wartości badanych współczynników w dwóch próbach niezależnych. W sytuacji gdy test Fishera-Snedecora wykazal, że na przyjętym poziomie istotności $\alpha=0,01$ nie ma podstaw do odrzucenia hipotezy zerowej o równości wariancji, weryfikacja hipotezy o równości dwóch średnich przeprowadzona została za pomocą testu $t$-Studenta. W przeciwnym przypadku wykorzystano test $t$-Studenta z modyfikacją Cochrana-Coxa (Stanisz, 2006: 224).

W badaniach posłużono się danymi pochodzącymi z Roczników Giełdowych, Biuletynów Statystycznych, bazy danych Notoria Serwis SA, bazy Emerging Markets Information Service (EMIS) oraz portalu finansowego Bankier.pl.

\section{Wyniki badań empirycznych nad wypłatą dywidendy w spółkach przemysłowych w kontekście stopnia koncentracji własności i kontroli}

Analiza spółek przemysłowych notowanych na GPW w Warszawie wykazała, iż dominującą formą kontroli właścicielskiej była tzw. kontrola od wewnątrz. W roku 2015 tę formę kontroli zaobserwowano łącznie w 97 przedsiębiorstwach, co stanowiło $66,4 \%$ badanej zbiorowości. Wśród spółek, w których strukturze akcjonariatu znaleźli się inwestorzy strategiczni, dominowały przedsiębiorstwa kontrolowane przez krajowe osoby fizyczne (24 podmioty - 16,4\% wszystkich analizowanych spółek) i krajowe osoby prawne (20 spółek - 13,7\%). Najmniej spółek, które w swojej strukturze właścicielskiej posiadały akcjonariusza strategicznego, zaobserwowano $\mathrm{w}$ przypadku przedsiębiorstw kontrolowanych przez zagraniczne osoby fizyczne i zagraniczne grupy osób fizycznych (po 1 spółce). Z kolei w 49 spółkach (tj. w 33,6\% badanej zbiorowości) sprawowanie kontroli właścicielskiej odbywało się „od zewnątrz” (zob. rys. 2).

W badanej grupie przedsiębiorstw dominowały spółki, które przynajmniej raz w pięcioletnim okresie analitycznym wypłaciły dywidendę pieniężną. Spółek tych było łącznie 78 (co stanowiło 53,4\% badanej zbiorowości). Wśród nich przeważały przedsiębiorstwa regularnie wypłacające dywidendę (było ich ponad dwukrotnie więcej niż spółek, w których dywidenda miała charakter nieregularny). Wśród spółek regularnie wypłacających dywidendę dominowały przedsiębiorstwa $\mathrm{z}$ akcjonariuszem strategicznym. Było ich 38, co stanowiło 71,7\% wszystkich spółek regularnie wypłacających dywidendę. Największą grupę tych spółek stanowiły przedsiębiorstwa, w których strukturze właścicielskiej dominowały krajowe osoby fizyczne, krajowe osoby prawne i spółki Skarbu Państwa - po 8 spółek. W grupie spółek z rozproszonym akcjonariatem 15 przeprowadziło regularne wypłaty dywidendy. Spółki te stanowiły $28,3 \%$ wszystkich spółek regularnie wypłacających 
dywidendę. Również w przypadku nieregularnych wypłat dywidendy dominowały przedsiębiorstwa, które posiadały akcjonariusza strategicznego - było ich 17. Spółki te stanowiły $68 \%$ wszystkich spółek wypłacających dywidendę nieregularną (zob. tab. 2).

Wśród spółek wypłacających dywidendę dominowały regularne wypłaty dywidendy. Sytuacja ta miała miejsce zarówno w przedsiębiorstwach, w których strukturze akcjonariatu występował akcjonariusz strategiczny, jak i w spółkach $\mathrm{z}$ akcjonariatem rozproszonym. W pierwszym przypadku spółek wypłacających dywidendę było więcej, jednak różnica ta nie była duża. Na wypłatę dywidendy zdecydowało się bowiem $69,1 \%$ spółek posiadających akcjonariusza strategicznego i $65,2 \%$ spółek, w których akcjonariat był rozproszony. Analizując udział spółek wypłacających dywidendę w ogóle badanych spółek, zauważyć należy, że w grupie przedsiębiorstw posiadających akcjonariusza strategicznego regularne wypłaty dywidendy miały miejsce w przypadku 39,2\% badanych spółek przemysłowych, a nieregularne wypłaty stanowiły $17,5 \%$ przypadków. Natomiast wśród przedsiębiorstw, których akcjonariat był rozproszony, spółki regularnie wypłacające dywidendę stanowiły $30,6 \%$, podczas gdy nieregularne wypłaty zaobserwowano w $16,3 \%$ przypadków (zob. rys. 2).

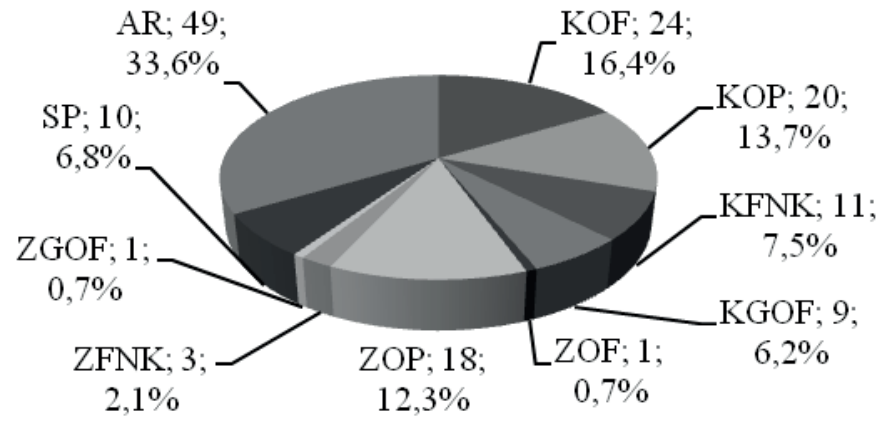

Rysunek 2. Koncentracja własności w spółkach przemysłowych na GPW w Warszawie w 2015 roku Źródło: opracowanie własne na podstawie: http://ir.notoria.pl/; http://www.bankier.pl/ 
Tabela 2. Regularność wypłat dywidendy w spółkach przemysłowych notowanych na GPW w Warszawie

\begin{tabular}{|c|c|c|c|c|c|c|c|c|c|c|}
\hline \multicolumn{3}{|c|}{ Wyszczególnienie } & \multicolumn{6}{|c|}{ Wypłata dywidendy } & \multirow{2}{*}{\multicolumn{2}{|c|}{ Razem }} \\
\hline \multirow{13}{*}{ 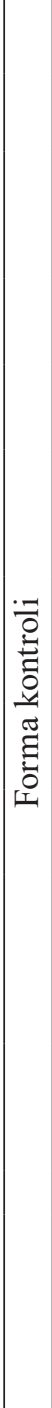 } & \multirow{12}{*}{ 胥 } & $\begin{array}{c}\text { Koncentracja } \\
\text { wlasności }\end{array}$ & \multicolumn{2}{|c|}{ Regularna } & \multicolumn{2}{|c|}{ Nieregularna } & \multicolumn{2}{|c|}{ Brak } & & \\
\hline & & & $\begin{array}{l}\text { Liczba } \\
\text { spólek }\end{array}$ & $\%$ & $\begin{array}{l}\text { Liczba } \\
\text { spólek }\end{array}$ & $\%$ & $\begin{array}{l}\text { Liczba } \\
\text { spólek }\end{array}$ & $\%$ & $\begin{array}{l}\text { Liczba } \\
\text { spółek }\end{array}$ & $\%$ \\
\hline & & $\begin{array}{l}\text { Akcjonariusz } \\
\text { strategiczny, } \\
\text { w tym: }\end{array}$ & 38 & 71,7 & 17 & 68,0 & 42 & 61,7 & 97 & 66,4 \\
\hline & & $\begin{array}{l}\text { Krajowa osoba } \\
\text { fizyczna }\end{array}$ & 8 & 15,1 & 5 & 20,0 & 11 & 16,2 & 24 & 16,4 \\
\hline & & $\begin{array}{l}\text { Krajowa osoba } \\
\text { prawna }\end{array}$ & 8 & 15,1 & 4 & 16,0 & 8 & 11,8 & 20 & 13,7 \\
\hline & & $\begin{array}{l}\text { Krajowe firmy } \\
\text { niepowiązane } \\
\text { kapitałowo }\end{array}$ & 4 & 7,6 & 2 & 8,0 & 5 & 7,4 & 11 & 7,5 \\
\hline & & $\begin{array}{l}\text { Krajowe grupy } \\
\text { osób fizycz- } \\
\text { nych }\end{array}$ & 5 & 9,4 & 1 & 4,0 & 3 & 4,4 & 9 & 6,2 \\
\hline & & $\begin{array}{l}\text { Zagraniczne } \\
\text { osoby fizyczne }\end{array}$ & 0 & 0,0 & 0 & 0,0 & 1 & 1,4 & 1 & 0,7 \\
\hline & & $\begin{array}{l}\text { Zagraniczne } \\
\text { osoby prawne }\end{array}$ & 5 & 9,4 & 3 & 12,0 & 10 & 14,7 & 18 & 12,3 \\
\hline & & $\begin{array}{l}\text { Zagraniczne } \\
\text { firmy niepo- } \\
\text { wiązane kapi- } \\
\text { tałowo }\end{array}$ & 0 & 0,0 & 1 & 4,0 & 2 & 3,0 & 3 & 2,1 \\
\hline & & $\begin{array}{l}\text { Zagraniczne } \\
\text { grupy osób } \\
\text { fizycznych }\end{array}$ & 0 & 0,0 & 0 & 0,0 & 1 & 1,4 & 1 & 0,7 \\
\hline & & Skarb Państwa & 8 & 15,1 & 1 & 4,0 & 1 & 1,4 & 10 & 6,8 \\
\hline & 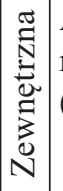 & $\begin{array}{l}\text { Akcjonariat } \\
\text { rozproszony } \\
\text { (AR) }\end{array}$ & 15 & 28,3 & 8 & 32,0 & 26 & 38,2 & 49 & 33,6 \\
\hline $\mathrm{Raz}$ & zem & & 53 & 100,0 & 25 & 100,0 & 68 & 100,0 & 146 & 100,0 \\
\hline
\end{tabular}

Źródło: opracowanie własne na podstawie: http://ir.notoria.pl/; http://www.bankier.pl/; https://www.emis.com/ 
W grupie spółek, w których występował akcjonariusz strategiczny, 43,3\% nie wypłaciło dywidendy ani razu w ciągu okresu analitycznego, podczas gdy w spółkach z rozproszonym akcjonariatem sytuacja ta miała miejsce w 53,1\% badanych podmiotów (zob. rys. 3).

a) spółki wypłacające dywidendę

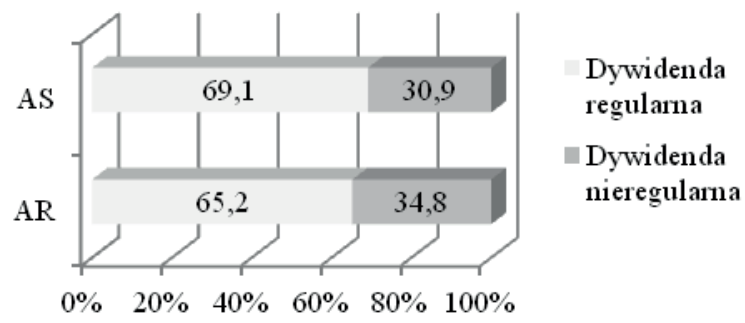

b) wszystkie spółki z sektora przemysłu

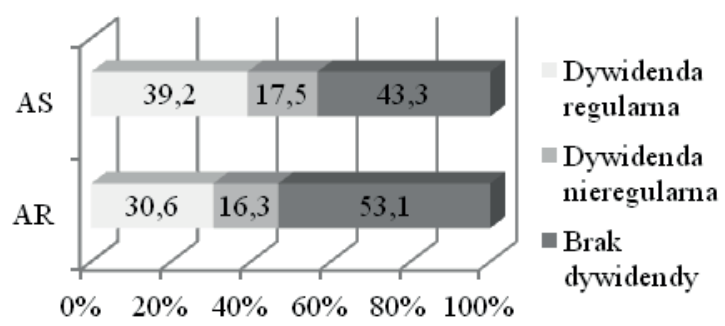

Rysunek 3. Koncentracja własności i kontroli a wypłata dywidendy pieniężnej (w \%)

Źródło: opracowanie własne na podstawie: http://ir.notoria.pl/; http://www.bankier.pl/; https://www.emis.com/

Wartość współczynnika niezależności $\chi^{2}$ dla relacji między stopniem koncentracji własności i kontroli a wypłatą dywidendy w spółkach przemysłowych znalazła się w obszarze krytycznym, co oznacza, że na przyjętym poziomie istotności $\alpha=0,01$ należy odrzucić hipotezę zerową o niezależności badanych zmiennych na rzecz hipotezy alternatywnej i stwierdzić, że między stopniem koncentracji własności i kontroli a regularnością wypłaty dywidendy istnieje zależność statystyczna. Wysokość współczynnika kontyngencji $C$-Pearsona równa 0,450 świadczy o umiarkowanej sile tej zależności. Otrzymane wyniki są istotne statystycznie ( $p$-value ukształtowało się na poziomie niższym niż 0,001) (zob. tab. 3). 
Tabela 3. Wartości współczynnika x² i współczynnika kontyngencji C-Pearsona dla zależności między stopniem koncentracji własności i kontroli a wypłatą dywidendy w spółkach przemysłowych

\begin{tabular}{|c|c|c|c|}
\hline $\begin{array}{c}\text { Współczynnik } \\
\text { niezależności } \chi^{\mathbf{2}}\end{array}$ & $\begin{array}{c}\text { Wartość krytyczna } \\
\boldsymbol{\chi}_{\mathbf{0}, 01 ; 1 \cdot \mathbf{2}}^{\mathbf{2}}\end{array}$ & $\begin{array}{c}\text { Współczynnik kontyngencji } \\
\boldsymbol{C} \text {-Pearsona }\end{array}$ & $\boldsymbol{p}$-value \\
\hline 36,971 & 9,210 & 0,450 & $<0,001$ \\
\hline
\end{tabular}

Źródło: opracowanie własne na podstawie: http://ir.notoria.pl/; http://www.bankier.pl/; https://www.emis.com/

Analiza wysokości wypłacanej dywidendy względem stopnia koncentracji własności i kontroli wykazała, że średnia wartość dywidendy na akcję, jak i jej mediana były w każdym roku okresu badawczego wyższe w przypadku spółek, w których strukturze właścicielskiej występował akcjonariusz strategiczny. Ponadto spółki te przeznaczały na wypłatę dywidendy zwykle większą część zysku netto niż spółki z akcjonariatem rozproszonym. Średnia roczna wysokość stopy wypłaty dywidendy w przypadku spółek posiadających akcjonariusza strategicznego była wyższa w czterech analizowanych latach, tj. w 2011, 2012, 2013 i 2015. Z kolei jej mediana ukształtowała się w przypadku tych spółek na wyższym poziomie w latach 2011-2013 (zob. tab. 4).

Tabela 4. Wysokość wypłaty dywidendy względem stopnia koncentracji własności i kontroli

\begin{tabular}{|c|c|c|c|c|c|c|}
\hline $\begin{array}{c}\text { Koncentracja wlasności } \\
\text { i kontroli }\end{array}$ & $\begin{array}{l}\text { Statystyki } \\
\text { opisowe }\end{array}$ & 2011 & 2012 & 2013 & 2014 & 2015 \\
\hline \multicolumn{7}{|c|}{ Dywidenda na akcję - DPS } \\
\hline \multirow[t]{2}{*}{ Akcjonariusz strategiczny } & Średnia $\bar{x}$ & 3,79 & 3,23 & 2,46 & 2,17 & 2,74 \\
\hline & Mediana $\mathrm{Me}$ & 0,55 & 0,55 & 0,44 & 0,59 & 0,67 \\
\hline \multirow[t]{2}{*}{ Akcjonariat rozproszony } & Średnia $\bar{x}$ & 0,82 & 0,88 & 1,76 & 1,12 & 1,03 \\
\hline & Mediana $M e$ & 0,51 & 0,50 & 0,40 & 0,51 & 0,37 \\
\hline \multicolumn{7}{|c|}{ Stopa wyplat dywidendy - DPR } \\
\hline \multirow[t]{2}{*}{ Akcjonariusz strategiczny } & Średnia $\bar{x}$ & 0,64 & 0,63 & 0,72 & 0,59 & 0,66 \\
\hline & Mediana $\mathrm{Me}$ & 0,56 & 0,55 & 0,63 & 0,54 & 0,49 \\
\hline \multirow[t]{2}{*}{ Akcjonariat rozproszony } & Średnia $\bar{x}$ & 0,55 & 0,55 & 0,69 & 0,60 & 0,61 \\
\hline & Mediana $\mathrm{Me}$ & 0,51 & 0,53 & 0,61 & 0,57 & 0,52 \\
\hline
\end{tabular}

Źródło: opracowanie własne na podstawie: http://ir.notoria.pl/; https://www.gpw.pl/biblioteka-gpw-lista?gpwlc_ $\mathrm{id}=10$; https://www.gpw.pl/biblioteka-gpw-lista?gpwlc_id=11

Na przyjętym poziomie istotności $(\alpha=0,01)$ należy odrzucić hipotezę zerową, stanowiącą, iż wysokość wypłacanej dywidendy nie różni się istotnie w zależności od stopnia koncentracji własności i kontroli spółek przemysłowych. W każdym roku okresu badawczego średnia wysokość stopy wypłat dywidendy różniła się znacząco ze względu na strukturę akcjonariatu badanych spółek $\left(t>t_{\alpha}\right.$ oraz $p$-value $<0,001$ ) (zob. tab. 5). 
Tabela 5. Wartości testów F-Snedecora, t-Studenta i p-value służące weryfikacji hipotezy o równości średnich wartości współczynników wypłaty dywidendy w spółkach o zróżnicowanej strukturze własności

\begin{tabular}{|c|c|c|c|c|c|c|}
\hline \multirow{2}{*}{ Wyszczególnienie } & \multirow{2}{*}{ Lata } & \multicolumn{2}{|c|}{ Test $\boldsymbol{F}$-Snedecora } & \multicolumn{2}{|c|}{ Test $\boldsymbol{t}$-Studenta } & \multirow{2}{*}{$p$-value } \\
\hline & & $\boldsymbol{F}$ & $F_{\alpha}$ & $t$ & $t_{\alpha}$ & \\
\hline \multirow{5}{*}{$\begin{array}{c}\text { Dywidenda } \\
\text { na akcję - DPS }\end{array}$} & 2011 & 63,25 & 6,06 & 0,13 & 2,83 & 0,898 \\
\hline & 2012 & 47,13 & 5,26 & 0,75 & 2,80 & 0,460 \\
\hline & 2013 & 3,54 & 4,65 & 0,14 & 2,71 & 0,889 \\
\hline & 2014 & 8,08 & 4,25 & 2,98 & 2,77 & 0,006 \\
\hline & 2015 & 18,31 & 5,15 & 2,92 & 2,76 & 0,007 \\
\hline \multirow{5}{*}{$\begin{array}{c}\text { Stopa wypłat } \\
\text { dywidendy }-D P R\end{array}$} & 2011 & 1,08 & 6,06 & 82,82 & 2,76 & \multirow{5}{*}{$<0,001$} \\
\hline & 2012 & 1,87 & 5,26 & 424,08 & 2,74 & \\
\hline & 2013 & 3,59 & 4,65 & 24,01 & 2,71 & \\
\hline & 2014 & 2,86 & 4,25 & 16,09 & 2,69 & \\
\hline & 2015 & 2,33 & 5,15 & 89,30 & 2,70 & \\
\hline
\end{tabular}

Źródło: opracowanie własne na podstawie: http://ir.notoria.pl/; https://www.gpw.pl/biblioteka-gpw-lista? gpwlc_id=10; https://www.gpw.pl/biblioteka-gpw-lista?gpwlc_id=11

Istotne statystycznie różnice między średnimi wartościami współczynnika „dywidenda na akcję" liczonego dla spółek, w których strukturze właścicielskiej występował akcjonariusz strategiczny oraz spółek z rozproszonym akcjonariatem, przypisać możemy tylko dla lat 2014 i 2015 ( $t>t_{\alpha}$ oraz $p$-value niższe odpowiednio od 0,006 i 0,007). Natomiast w okresie od 2011 do 2013 roku nie ma podstaw do odrzucenia hipotezy zerowej stanowiącej, że spółki przemysłowe o zróżnicowanej strukturze akcjonariatu nie różnią się od siebie istotnie pod względem wysokości wypłaty dywidendy jednostkowej $\left(t<t_{\alpha}\right)$. Zauważyć jednak należy, że w tym przypadku wynik testu $t$-Studenta nie jest istotny statystycznie na wybranym poziomie istotności. W roku 2011 p-value wyniosło bowiem 0,898 , w roku 2012 było równe 0,460, a w roku 2013 ukształtowało się na poziomie 0,889 (zob. tab. 5).

\section{Podsumowanie}

Badania empiryczne wykazały, że w analizowanej grupie spółek między stopniem koncentracji własności i kontroli a regularnością wypłaty dywidendy istnieje istotna statystycznie zależność. Należy zatem stwierdzić, że hipoteza badawcza H1 zweryfikowana została pozytywnie. W spółkach, w których struktura akcjonariatu odznaczała się silną koncentracją własności i kontroli, zaobserwowano wypłatę większej części zysku netto niż w podmiotach, w których dominował akcjonariat rozproszony. Można zatem skonstatować, iż hipoteza badawcza H2 została potwierdzona. 
Zaprezentowane $\mathrm{w}$ artykule wnioski badawcze są rezultatem analizy przeprowadzonej w oparciu o jeden czynnik mogący determinować wypłatę dywidendy pieniężnej. W praktyce gospodarczej decyzje o podziale zysku netto na zysk zatrzymany i dywidendę warunkowane są wieloma różnorodnymi czynnikami. W związku z tym przedstawione wyniki badań powinny stać się przyczynkiem do dalszych i pełniejszych analiz prowadzonych z uwzględnieniem pozostałych determinant wypłaty dywidendy pieniężnej.

\section{Bibliografia}

Adamska A. (2011), Systemy nadzoru korporacyjnego na świecie, „Ekonomia i Prawo”, nr 7, s. 67-77. Aydin A.D., Cavdar S.C. (2015), Corporate Governance and Dividend Policy: An Empirical Analysis From Bursa Istanbul Corporate Governance Index, „Accounting and Finance Research”, vol. 4, no. 3, s. 66-76, http://dx.doi.org/10.5430/afr.v4n3p66.

Baker M., Wurgler J. (2004), Appearing and Disappearing Dividends: the Link to Catering Incentives, ,Journal of Financial Economics”, vol. 73, no. 2, s. 271-288, http://dx.doi.org/10.1016/j. jfineco.2003.08.001.

Binek B., Heciak P., Stępniewski M., Waltz-Komierowska D. (2006), Prawa i obowiązi akcjonariuszy spótek publicznych, Komisja Nadzoru Finansowego, Warszawa.

Black F. (1976), The Dividend Puzzle, „Journal of Portfolio Management”, vol. 2, no. 2, s. 5-8, http://dx.doi.org/10.3905/jpm.1976.408558.

Claessens S., Djankov S. (1999), Ownership Concentration and Corporate Performance in the Czech Republic, „Journal of Comparative Economics”, vol. 27, no. 3, s. 498-513.

DeAngelo H., DeAngelo L., Stulz R. (2006), Dividend policy and the earned/contributed capital mix: a test of the life-cycle theory, ,Journal of Financial Economics”, vol. 81, no. 2, s. 227254, http://dx.doi.org/10.1016/j.jfineco.2005.07.005.

Domański C. (2001), Metody statystyczne. Teoria i zadania, Wydawnictwo Uniwersytetu Łódzkiego, Łódź.

Duraj A.N. (2002), Czynniki realizacji polityki wypłat dywidendy przez publiczne spółki akcyjne, Wydawnictwo Uniwersytetu Łódzkiego, Łódź.

Eije H., Megginson W.L. (2008), Dividends and Share Repurchases in European Union, ,Journal of Financial Economics", vol. 89, no. 2, s. 347-374, http://dx.doi.org/10.1016/j.jfineco.2007.11.002.

Elson J.A., Hofler R., Lee J. (2011), Dividend Policy and Institutional Ownership: Empirical Evidence using a Propensity Score Matching Estimator, „Journal of Accounting and Finance”, vol. 11, no. 1, s. 105-122.

Fisher K.L., Statman M. (2000), Cognitive Biases In Market Forecast, „Journal of Portfolio Management", vol. 27, no. 1, s. 72-81, http://dx.doi.org/10.3905/jpm.2000.319785.

French D.W., Varson P.L., Moon K.P. (2005), Capital Structure and the Ex-Dividend Day Return, „The Financial Review”, vol. 40, s. 361-379, http://dx.doi.org/10.2139/ssrn.176932.

Fuller K. Goldstein M. (2011), Do Dividends Matter More in Declining Markets?, „Journal of Corporate Finance", vol. 17, no. 3, s. 457-473, http://dx.doi.org/10.1016/j.jcorpfin.2011.01.001.

Gajdka J. (2013), Behawioralne finanse przedsiębiorstw, Wydawnictwo Uniwersytetu Łódzkiego, Łódź.

Gugler K., Yurtoglu B.B. (2003), Corporate governance and dividend pay-out policy in Germa$n y$, ,European Economic Review”, vol. 47, no. 4, s. 731-758, http://dx.doi.org/10.1016/S00142921(02)00291-X. 
Hamrol M., Ochocki B. (2008), Wpływ struktury akcjonariatu na efektywność gospodarowania przedsiębiorstw, „Zeszyty Naukowe Uniwersytetu Szczecińskiego. Finanse, Rynki Finansowe, Ubezpieczenia", nr 14, s. 287-298.

http://ir.notoria.pl/ [dostęp: 1.02.2016].

http://www.bankier.pl/ [dostęp: 8.02.2016].

https://www.emis.com/ [dostęp: 8.02.2016].

https://www.gpw.pl/biblioteka-gpw-lista?gpwlc_id=10 [dostęp: 10.02.2016].

https://www.gpw.pl/biblioteka-gpw-lista?gpwlc_id=11 ]dostęp: 10.02.2016].

Jensen G.R., Solberg D.P., Zorn T.S. (1992), Simultaneous Determination of Insider Ownership, Debt and Dividend Policies, „The Journal of Financial and Quantitative Analysis”, vol. 27, no. 2, s. 247-263, http://dx.doi.org/10.2307/2331370.

Jensen M. (1986), Agency Cost of Free-Cash-Flow, Corporate Finance and Takeovers, „American Economics Review", vol. 76, no. 2, s. 323-329.

Jerzemowska M. (2004), Analiza ekonomiczna w przedsiębiorstwie, PWE, Warszawa.

Kaźmierska-Jóźwiak B. (2014), Czynniki polityki dywidendowej w warunkach polskich, „Annales Universitatis Mariae Curie-Skłodowska”, vol. 48, s. 129-135.

Kowalewski O., Stetsyuk I., Talavera O. (2007), Corporate Governance and Dividend Policy in Poland, „Bank i Kredyt”, nr 38, s. 60-86, http://dx.doi.org/10.2139/ssrn.986111.

Kowerski M. (2010), Wpływ nastrojów gospodarczych przedsiębiorców i konsumentów na decyzje dywidendowe spótek kapitałowych, ,Barometr Regionalny”, nr 2(20), s. 19-34.

La Porta R., Lopez F., Shleifer A., Vishny R (2000), Agency Problems and Dividend Policies Around the World, ,Journal of Finance”, vol. 55, no. 1, s. 1-34.

Lintner J. (1956), Distribution of Incomes of Corporation Among Dividends, Retained Earnings and Taxes, „American Economic Review”, vol. 46, no. 2, s. 97-113.

Matuszewska-Pierzynka A. (2015), Net Profit Distribution Policy in Companies Using State-owned Enterprises Against Payment, „Quarterly Journal Oeconomia Copernicana”, vol. 6, no. 2, s. 89-107, http://dx.doi.org/10.12775/OeC.2015.014.

Mitton T. (2005), Corporate Governance and Dividend Policy in Emerging Markets, „Emerging Markets Review", vol. 5, no. 4, s. 409-426, http://dx.doi.org/10.1016/j.ememar.2004.05.003.

Pieloch A. (2012), Motywy i efekty wykupu akcji własnych, Wydawnictwo Uniwersytetu Łódzkiego, Łódź.

Pieloch A. (2013), Dywidenda niepieniężna jako narzędzie restrukturyzacji kapitałowej $i$ właścicielskiej przedsiębiorstwa, [w:] R. Borowiecki, J. Chadam, J. Kaczmarek (red.), Zachowania przedsiębiorstw w obliczu nowych wyzwań gospodarczych, Fundacja Uniwersytetu Ekonomicznego w Krakowie, Kraków.

Ramli N.M. (2010), Ownership Structure and Dividend Policy. Evidence from Malaysian Companies, „International Review of Business Research Papers”, vol. 6, no. 1, s. 170-180.

Renneboog L., Trojanowski G. (2005), Patterns in Payout Policy and Payout Channel Choice of UK Firms in the 1990s, „Journal of Banking \& Finance”, vol. 35, no. 6, s. 1477-1490, http://dx.doi. org/10.1016/j.jbankfin.2010.10.028.

Rocznik Giełdowy (2013), Giełda Papierów Wartościowych w Warszawie, Warszawa.

Short H., Zhang H., Keasey K. (2002), The Link between Dividend policy and Institutional Ownership, „Journal of Corporate Finance”, vol. 8, no. 2, s. 105-122.

Sierpińska M. (1999), Polityka dywidend w spótkach kapitałowych, Wydawnictwo Naukowe PWN, Warszawa-Kraków.

Stanisz A. (2006), Przystęny kurs statystyki z zastosowaniem STATISTICA PL na przyktadach z medycyny. Tom. 1, StatSoft, Kraków.

Szyszka A. (2013), Behavioral Finance and Capital Markets, Palgrave MacMillan Palgrave Macmillan, New York. 
Ullah H., Fida A., Khan S. (2012), The Impact of Ownership Structure on Dividend Policy. Evidence form Emerging Markets KSE-100 Index Pakistan, „International Journal of Business and Social Science", vol. 3, no. 9, s. 289-307.

Ustawa z dnia 15 września 2000 r. Kodeks spółek handlowych (Dz.U. Nr 94, poz. 1037).

Wypych M. (2015), Koncentracja własności a wypłata dywidend na przykładzie przemystowych spólek giełdowych, ,Zeszyty Naukowe Uniwersytetu Szczecińskiego. Finanse, Rynki Finansowe, Ubezpieczenia", nr 73, s. 783-792.

\section{Concentration of Ownership and Control Versus Dividend Payment in Industrial Companies Listed on the Warsaw Stock Exchange}

Abstract: The purpose of this article is to present the results of empirical research on the relationship between a degree of concentration of ownership and control with regularity and amount of dividend payment. Two hypotheses were set. Hypothesis $\mathrm{H} 1$ stipulates that companies with a high degree of concentration of ownership and control pay dividends more regularly than other companies. Hypotheses $\mathrm{H} 2$ stating that in the companies whose ownership and control are concentrated, we observe the higher dividend payments than in the companies with dispersed ownership. The analysis was conducted on industrial companies listed on the Warsaw Stock Exchange in the period between 2010-2015. The results of empirical research confirmed both hypotheses.

Keywords: ownership concentration, dividend policy, industrial companies

JEL: G10, G31, G35

\begin{tabular}{|l|l|}
\hline \multirow{2}{*}{ OPEN ACCESS } & $\begin{array}{l}\text { C by the author, licensee Łódź University - Łódź University Press, Łódź, Poland. } \\
\text { This article is an open access article distributed under the terms and conditions } \\
\text { of the Creative Commons Attribution license C(-BY } \\
\text { (http://creativecommons.org/licenses/by/3.0/) }\end{array}$ \\
\cline { 2 - 2 } & Otrzymano: 2016-05-06; po weryfikacji: 2016-11-08. Zaakceptowano: 2017-02-15 \\
\hline
\end{tabular}

